\title{
STVARANJE INOVATIVNIH KOMPETENCIJA KOD STUDENATA INŽENJERSKO-TEHNOLOŠKOG PROFILA
}

\section{Duško Radaković1, Dragan Cvetković2 Zoran Radaković ${ }^{3}$}

\author{
${ }^{1}$ Visoka škola strukovnih studija - \\ Beogradska politehnika, \\ Beograd, Srbija \\ 2Univerzitet Singidunum, \\ Beograd, Srbija \\ ${ }^{3}$ Mašinski fakultet, \\ Univerzitet u Beogradu, \\ Beograd, Srbija
}

Correspondence:

Duško Radaković

e-mail:

dradakovic@politehnika.edu.rs

\begin{abstract}
Rezime:
Imajući na umu sve brži rast znanja usled napretka u nauci i tehnologiji, za rešavanje globalnih problema nije dovoljno razmišljati o njima na isti način kada su i stvarani. Rešenja ne leže unutar jednog domena, nauke ili tehnologije. Za rešavanje današnjih globalnih problema potreban je integrisani pristup po mnogim domenima, naukama ili tehnologijama. Znanje i shvatanje čoveka ograničeno je njegovim iskustvom, obrazovanjem i istraživanjem. Međutim, napredak u nauci i tehnologiji zahteva više od ovoga. Pregledom postojeće literature i inovacija u svetu, u ovom radu prikazana je studija na osnovu koje je potrebno stvoriti nove sposobnosti i kompetencije kod budućih inženjera i tehnologa, sa drugačijim načinom razmišljanja. Biomimikrijski pristup omogućava suočavanje sa globalnim problemima u kontekstu kreiranja održivog sveta. Zbog ovoga je potrebna da se inženjerski i tehnološki studijski programi prevedu na globalniji model, model koji bi integrisao biomimikrijski pristup kao sredstvo da pripremi buduće inženjere i tehnologe da na drugačiji, inovativniji način razmišljaju o globalnim problemima i njihovom rešavanju.
\end{abstract}

Ključne reči:

biomimikrija, obrazovanje, kompetencije.

\section{UVOD}

Svet je u opasnosti zbog velikog uticaja industrije koju je čovek stvorio, direktno ili indirektno. Dovoljno je samo da pogledamo preko ramena i uočimo kako priroda funkcioniše, da bismo znali da smo godinama unazad probleme rešavali sa posledicama koje danas predstavljaju globalne probleme. Visoko obrazovanje mora da preispita svoju ulogu u obučavanju budućih inženjera koji će se baviti ovom problematikom. Da bi budući inženjer mogao uspešno da rešava ovakve probleme, ali i druge probleme čija rešenja neće ugrožavati održivost sredine, inženjerski kurikulum mora da se preobrazi u globalni obrazovni model. Mora da integriše inovativne sposobnosti i kompetencije koje omogućavaju da se na nov način razmišlja o globalnim problemima. U osnovi, ključna pitanja koja se odnose na ovaj novi globalni obrazovni model mogu se formulisati na sledeći način:

1. Koja su to neophodna znanja i uslovi za rešavanje složenih globalnih problema?

2. Koji su to izvori saznanja o prirodi koji su najprimenljiviji? 


\section{PREGLED LITERATURE}

Prateći kurikulume mnogih inženjerskih studija, uočili smo da se ogroman broj i dalje realizuje po tradicionalnim procesima rešavanja problema radi kreiranja mehaničkih i elektronskih rešenja. Ovi nastavni kurikulumi trebalo bi da objedine i način kako da se imitira i emulira priroda kao komponenta prilikom učenja studenata rešavanju globalnih problema. Za ovo je potreban interdisciplinarni pristup koji bi povezao inženjere i naučnike na saradnju i obostrano učenje. Potrebno je obuhvatiti sistemsko razmišljanje, dizajn, materijale, komunikaciju, energiju, alate i ljudske sisteme. Razlika u odnosu na sadašnji kurikulum inženjerskog obrazovanja je u tome što bi se baza znanja i adekvatne sposobnosti i kompetencije vrtele oko toga kako u prirodi funkcionišu sistemi i ciklusi, i kako da se ova informacija iz prirode iskoristi u kreiranju analogija kojima se stvaraju nova rešenja.

Svega nekoliko ljudi u svetu identifikovalo je nove sposobnosti i kompetencije koje se odnose na biomimikriju. Janine Benyus obezbeđuje temelj za razumevanje kako nauka imitira prirodu za rešavanje problema [1]. Razmišljajući na ovakav način o energetici, klimatskim promenama, manjku vode, skladištenju otpada, zdravlju i kritičnim infrastrukturnim problemima, dolazimo do novih, održivih rešenja. Međutim, potrebno je rastumačiti koje su to biomimikrijske sposobnosti i kompetencije koje su najznačajnije i najpogodnija za proučavanje globalnih problema.

\section{Šta je biomimikrija?}

Biomimikrijski pristup (negde se pominje i termin biomimetika) ljudi su od davnina koristili kada su koncepte iz prirode koristili za rešavanje složenih problema (Leonardo da Vinci, Matthew Baker, Ser Joseph Paxston, Joseph Monier, Alexandre Gustav Eiffel, George de Mestral i drugi). Izvorno, naziv biomimetika skovao je Schmitt [2] i po njegovom mišljenju to je nauka o sistemima i supstancama u prirodi, koji se koriste za pronalaženje rešenja na ljudske i tehničke probleme. $S$ druge strane, biomimetika (biomimikrija) je naziv za kombinaciju nauka (biologije, hemije, matematike i fizike) u cilju proučavanja struktura i funkcija bioloških sistema kao modela za konstruisanje raznih sistema i materijala u tehnologiji [3]. Po mišljenju Janine Benyus, biomimikrija je nova nauka koja proučava modele u prirodi a zatim ih imitira ili koristi njihov princip za rešavanje ljudskih problema.

Iz prirode se mogu izvući ključni koncepti i karakteristike koje upravljaju načinom kako sistemi i ciklusi u prirodi funkcionišu i kako odolevaju vremenu. Ovi sistemi i ciklusi brinu sami o sebi. Priroda uklapa oblik prema funkciji. Priroda evoluira. Ona samostalno eksperimentiše kako bi unapredila žive organizme, procese i materijale u prirodi. U prirodi, otpad za jedan sistem je hrana za drugi sistem. Ekosistemi u prirodi brinu se o transformaciji hrane iz jednog oblika u drugi. Energetski izvor u prirodi je sučevo zračenja. Ista energija pokreće sve sisteme i cikluse u prirodi - zemlju, vodu, atmosferu. U potpunosti je efikasan sistem jer koristi samo onoliko energije koliko je potrebno. Priroda je samopovezujuća jer njeni sistemi i ciklusi sarađuju međusobno. U prirodi nema ni viška ni manjka. Veza između sistema i ciklusa zasniva se na različitosti. U prirodi je ustaljen koncept „od kolevke do kolevke", koncept u kojem nema otpada, već se umesto toga otpad eliminiše konceptom uređenja $[1,4,5]$. Suprotno ovoj filozofiji (od kolevke do kolevke), filozofija industrijskog doba bila je zasnovana na konceptu „od kolevke do groba”. Umesto nula otpada, proizvodi iz industrijskog doba projektovani su tako da gotovo $90 \%$ materijala u tim proizvodima momentalno postaje otpad. Za razliku od sistema i ciklusa u prirodi koji proizvode više energije nego što potroše, proizvodnja u industriji koristila je više energije nego što može da proizvede. Ako se na ovakav način razmišlja, u velikoj meri se pojačavaju sposobnosti za rešavanje, upravljanje i kontrolu većih globalnih problema.

\section{ANALIZA}

$\mathrm{Na}$ osnovu dostupne literature koja se bavi biomimikrijskim pristupom inovacija sposobnosti, u Tabeli 1 sumarno su prikazane inovativne sposobnosti i kompetencije prema instituciji ili istraživaču.

\begin{tabular}{ll}
\hline Institucija/Istraživač & Sposobnosti i kompetencije \\
\hline & Poznavanje analogija radi \\
razumevanja kako imitirati \\
prirodu za rešavanje \\
problema; \\
Razumevanje istorije prirode \\
i života pre ljudi; \\
Detaljno i sistematsko \\
poznavanje određenih grupa \\
organizama; \\
Poznavanje kako uklo- \\
piti prirodni dizajn i procese \\
prema potrebama inženjera i \\
tehnologa; \\
Potreba za zajedničkim \\
radom biologa i inženjera; \\
Razumevanja kako „skalirati” \\
dizajn, procese i različitost u \\
prirodi. \\
\end{tabular}




\begin{tabular}{ll}
\hline & Kako skalirati rešenja; \\
& Razumevanje nauke o \\
materijalima u prirodi; & Razumevanje strukture \\
& materijala u prirodi; \\
& Razumevanje sistema i \\
& ciklusa u prirodi; \\
& Razumevanje tehnologije \\
koja postoji u živim stvoren- & jima. \\
& \\
\hline Kevin Passino [7] & Biološki procesi; \\
& Rešavanje problema; \\
& Matematičko modelovanje; \\
& Računarske simulacije; \\
& Tehnološke operacije. \\
\hline John Reap [8] & Biorazličitost; \\
& Veza između hidrofobičnih \\
& mikro i nanostrukturnih \\
& površina i adhezije čestica; \\
& Inženjerstvo ekosistema. \\
& Kako ugraditi biologiju u \\
proces dizajniranja; & Kako ugraditi biomimikriju \\
& K dizajn; \\
& Kako raditi u \\
interdisciplinarnim \\
timovima; \\
Kako ugraditi biomimikriju u \\
inženjerski proces; \\
Komunikacija između \\
inženjera i poslovnih ljudi u \\
smislu biomimikrije; \\
Kako biolozi prikupljaju \\
informacije i dele sa drugim \\
disciplinama; \\
Koje su osnove poslovnog \\
razvoja i donošenja odluka; \\
Primena metodologije \\
biomimikrije. \\
Razumevanje principa života. \\
\end{tabular}

Tabela 1. Sposobnosti i kompetencije.

Kada se uporede biološki ciklusi prirode sa tehničkim ciklusima u industriji, mogu se izvući principi koji se oslanjaju na biomimikrijsko rešavanje problema. Na ovaj način, stiče se razumevanje fenomena u prirodi $i$ kako se stvaraju idealna okruženja. U tradicionalnom pristupu, inženjeri primenjuju naučne teorije ili tehnološka otkrića. Međutim, biomimikrijski pristup zahteva integrisano razmišljanje. Za rešavanje složenih globalnih problema ljudi moraju da usvoje i primene sisteme i cikluse iz prirode na tehničke sisteme (pa i na ljudske sisteme) u svetu. Da bi ovo moglo da se uradi, potrebne su izoštrene veštine posmatranja funkcija prirodnih sistema i kako ih primeniti u tehnički sistem. U Tabeli 2 prikazana su neka od znanja koji se odnose na inženjersko-tehnološke studijske programe.

\begin{tabular}{cl}
\hline Studijski program & Primeri primene znanja \\
\hline Razumevanje kako priroda \\
uklapa oblik prema funkiji; \\
Razumevanje strukture lišća \\
za projektovanje zgrada; \\
Razumevanje termitnjaka za \\
projektovanje ventilacionih \\
sistema u zgradama. \\
Razumevanje leta i oblika \\
ptica za projektovanje \\
vazduhoplova; \\
Razumevanje adheziva kod \\
dagnji kojim se vezuju za \\
stene; \\
Razumevanje struktura \\
biljaka kao sredstvo za bolji \\
dizajn automobila; \\
Razumevanje ljuski i egzos- \\
keleta insekata radi povećanja \\
površinske tvrdoće \\
materijala. \\
\hline Proizvodnja
\end{tabular}

Tabela 2. Primeri primene biomimikrijskih saznanja u određena polja obrazovanja.

Da bi se mogao stvoriti mentalni model za rešavanje složenih globalnih problema, potrebno je razumeti kako sistemi i ciklusi u prirodi funkcionišu i ceniti način na koji isti ti sistemi i ciklusi rade sa ljudskim sistemima. U Tabeli 3 prikazani su neki od ključnih izvora znanja, odnosno elementi iz prirodnih sistema i ciklusa koji mogu da se primene na današnje kurikulume inženjerskih studija. 


\begin{tabular}{|c|c|}
\hline Sistemi i ciklusi u prirodi & Primenjivo znanje \\
\hline \multirow{2}{*}{ Bio-geo-hemijski ciklusi } & $\begin{array}{l}\text { Razmena biosfera-okeani- } \\
\text { atmosfera; }\end{array}$ \\
\hline & $\begin{array}{l}\text { Razmena biosfera-atmosfera } \\
\text { iznad kopna. }\end{array}$ \\
\hline \multirow{3}{*}{ Ciklusi ugljenika } & $\begin{array}{l}\text { Kako biljke apsorbuju } \\
\text { ugljen-dioksid iz atmosfere; }\end{array}$ \\
\hline & $\begin{array}{l}\text { Kako životinje koriste } \\
\text { ugljenik za izgradnju } \\
\text { sopstvenog tkiva; }\end{array}$ \\
\hline & $\begin{array}{l}\text { Kako se atomi ugljenika } \\
\text { ugrađuju u proces } \\
\text { fotosinteze. }\end{array}$ \\
\hline \multirow{3}{*}{ Ekološki ciklusi } & Hidrologija; \\
\hline & Nauka o vegetaciji; \\
\hline & Bio-različitost. \\
\hline \multirow{5}{*}{ Energetski ciklusi } & Fotosinteza; \\
\hline & Solarno zračenje; \\
\hline & Transformacija; \\
\hline & Distribucija; \\
\hline & Transport. \\
\hline \multirow{3}{*}{ Hidro ciklusi } & Vlažnost zemljišta; \\
\hline & Karakteristike terena; \\
\hline & Bilans vode. \\
\hline \multirow{4}{*}{ Biljni svodovi } & Struktura biljaka; \\
\hline & Adaptacija; \\
\hline & Eliminacija otpada; \\
\hline & Adhezija čestica. \\
\hline
\end{tabular}

Tabela 3. Primenjiva znanja iz prirodnih sistema i ciklusa.

Sada se postavlja pitanje: kako struktuirati ova znanja u obrazovne programe? U inženjersko-obrazovnim programima, znanje je uobičajeno struktuirano unutar domena, nauke ili tehnologije. Mali je broj programa koji su bazirani na integrisanom modelu. Shodno tome, nove kompetencije i sposobnosti se formiraju na tradicionalan način - kao mehanička, fizička ili elektronska rešenja. Bilo je mnogo predloga kako da se identifikuje analogija inovacija. Po mišljenju nekih, projektni tim ograničen je znanjem koje poseduju njegovi članovi. Drugi predlažu biološki okvir jer može da se primeni na više različitih platformi [11].

Sa druge strane, J. Barnes, S. Barnes i D. Dyrenfurth identifikuju više faktora koji ograničavaju razmišljanje o prirodi, a time ograničavaju održiva rešenja bazirana na biomimikriji [12]. Prema njihovom mišljenju, prvi faktor - oskudica, odnosi se na princip po kojem se sve što nam je potrebno za preživljavanje nalazi direktno ili indirektno u našem prirodnom okruženju. Direktno iz ovog sledi da je neophodno sastavljanje interdisciplinarnih timova naučnika i inženjera kako bi se uspešno imitirala i emulirala priroda u kontekstu rešavanja globalnih problema.
Nedostatak integracije, pre svega, odnosi se na neuspeh interesnih grupa i eksperata da stvore analogije i modele sistema i ciklusa prirode koji bi mogli da se primene na tehničke sisteme. Pored ovoga, limitirajući faktor je i nedostatak volje za promenama. U tom kontekstu, neki naučnici imaju otpor prema radu inženjera, a takođe i neki inženjeri ne žele da rade sa naučnicima. Ovo može da se tumači kao opiranje zajednice da prihvati održivo rešenje. Otpad je svakako jedan od ograničavajućih faktora jer postoji nemogućnost da se procesi podignu na zadovoljavajući nivo otpada, odnosno da se dostigne nula-otpad u kontekstu prirodnog, održivog sistema. Konačno, ograničavajući faktor je i rizik, odnosno nivo rizika koji se odnosi na prepreku kojom prirodna, održiva rešenja nisu dovoljno bezbedna da bi se sprovela u delo, odnosno zajednica ne može da prihvati takvo rešenje zbog apriori usađenih ubeđenja u vezi sa nivoom rizika predloženog rešenja.

Pored ovakvih ograničavajućih faktora, takođe mora postojati sposobnost da se rešenja adekvatno skaliraju kada se unose u jednačinu rešenja. $U$ vezi sa ovim skaliranjem rešenja pri rešavanju globalnih problema, potrebno je voditi računa o razmerama potrebe, razmerama potrebnih investicija za stvaranje alternativa, i srazmerno potrebnom vremenu za proizvodnju alternativa. S obzirom na to da će do 2050 . godine broj ljudi na Zemlji verovatno premašiti 9,3 milirade stanovnika, mogućnosti da se složeni globalni problemi skaliraju na lokalne ili regionalne gotovo je nemoguće. Upravo zbog toga potrebno je da se i druga razmatranja ugrade u jednačinu rešavanja složenih globalnih problema, koja bi imala trenutni uticaj i dugoročne efekte na nova rešenja. Ovi uticaji i efekti mogu biti različite prirode lične, društvene, kulturalne, političke, ili da se odnose na okruženje. Bez obzira na značajna znanja i posvećenost rešavanju složenih globalnih problema, transdisciplinarni tim eksperata i investitora ne može znati, a ni rešavati, potencijalne uticaje i posledice. Dešava se da ponekad nauka i tehnologija daju podršku za rešenje, ali se uticaji i posledice mogu sagledati tek nekoliko decenija kasnije.

\section{INOVACIONE SPOSOBNOSTI I KOMPETENCIJE BUDUĆIH INŽENJERA I TEHNOLOGA}

U poslednjih nekoliko decenija, mnogo istraživača, instituta i univerziteta posvećuje više pažnje na razvijanje novih biomimikrijskih sposobnosti i kompetencija. S obzirom na istraživanja koja su sproveli istraživači, institucije i univerziteti, može se objediniti obimna 
lista predloženih sposobnosti i kompetencija (u Tabeli 4 prikazane su neke od njih).

\section{Sposobnosti kompetencije bazirane na biomimikriji}

Sposobnost da se imitira i emulira priroda;

Sposobnost za kritičko razmišljanje;

Sposobnost da se koriste koncepti biomimikrije za rešavanje problema;

Razumevanje ciklusa i sistema u prirodi;

Razumevanje koncepta prilagodljivosti i kako se primenjuje u prirodi;

Razumevanje strukture organizama i vrsta u prirodi;

Razumevanja kako priroda samu sebe skalira;

Razumevanje faktora održivosti;

Razumevanje principa biomimikrije;

Razumevanje mentalnog modela za prevođenje prirode $\mathrm{u}$ cilju pronalaženja rešenja za globalne probleme;

Razumevanje složenih sistema;

Razumevanje sistemskog razmišljanja;

Razumevanje struktura u prirodi;

Razumevanje nauke o materijalima u prirodi.

Tabela 4. Inovacione sposobnosti i kompetencije.

Danas se svet suočava sa jednom od najvećih ekonomskih kriza u istoriji čovečanstva. Posebno razvijene zemlje, jer se rat preneo i na ekonomiju zemalja. Mogućnost da se razvije potrebna inovativnost koja bi doprinela rešavanju globalnih problema posebno ometaju politika, lobisti i sistemi visokog obrazovanja koji ne žele da uvedu promene i odreknu se tradicije. Potrebno je što pre usvojiti nove paradigme istraživanja i inovacija koje bi omogućile proučavanje glavnih problema, kao što su energetika ili kritična infrastruktura. Ovakva, nova paradigma, mogla bi da omogući stvaranje novih proizvoda, usluga, novih radnih mesta, smanji nezaposlenost itd. Na primer, tradicionalni pristup koristi sistemsko-teorijski pristup u proučavanju globalnih problema koji se odnose na dinamiku nauke, tehnologije i inovacije, kao i njihovoj vezi sa ekonomskim rastom. Međutim, ovakav pristup je po svojoj prirodi ograničen za rešavanje globalnih problema. Obrazovni studijski programi inženjera moraju se promeniti kako bi pripremili studente da budu efikasniji inženjeri u rešavanju kritičnih globalnih problema. Novi kurikulumi bi trebalo da pređu na globalniji obrazovni model, posebno takav da integriše sposobnosti inovacija i kompetencija kojim se razvija novi način razmišljanja u vezi sa globalnim problemima. Jedan od načina da se ovo realizuje jeste da se težište prenese na komponente programa čiji je fokus na kritičkom razmišljanju i rešavanju složenih problema. Paralelno sa ovim treba razvijati mentalne modele na osnovu analogija, metafora i drugih tehnika analize. Ovi mentalni modeli bili bi od ogromne pomoći da studenti bolje sagledaju nova okruženja primenjujući znanja iz sličnog (poznatog) okruženja. Integracijom biomimikrijskog pristupa u obrazovanje inženjera i tehnologa u velikoj meri može da doprinese razvoju neophodnog kritičkog razmišljanja i veština rešavanja problema koje su potrebne budućem inženjeru ili tehnologu.

\section{Biomimikrijski pristup u praksi}

Postoji mnoštvo primera u kojima je korišćen biomimikrijski pristup kod projektovanja novih proizvoda. Jedan od njih je projektovanje japanskog brzog voza (Shikansen). Problem je bila buka koju je stvarao voz, posebno pri izlasku iz tunela. Inspiracija rešenja viđena je kod ptice vodomar (Slika 1).
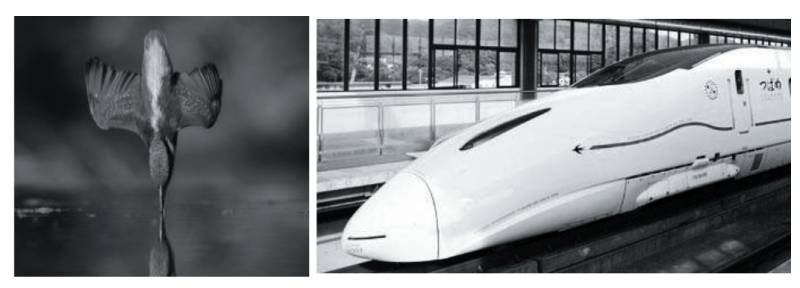

Slika 1. Japanski brzi voz Shikansen po uzoru na kljun vodomara.

Drugi primer je stvaranje čistih okruženja ili površina, površina bez bakterija. Kao prirodni model poslužila je ajkula sa Galapagosa. Naime, ove ajkule na svojoj koži nemaju nikakve parazite ni bakterije, sve to zahvaljujući strukturi teksture kože ove ajkule. Komapnija Sharklet Technologies Inc. predstavila je prvu tehnologiju na svetu koja inhibira rast bakterija kroz samu formu. Šarklet površina sastoji se od miliona mikroskopskih obrazaca raspoređenih po posebnom dijamant uređenju. Sama struktura (Slika 2) sprečava da se bakterije vezuju, kolonizuju i formiraju biofilmove. Šarklet ne sadrži toksične aditive ili hemikalije, i ne koristi antibiotike ili antimikrobna sredstva.

Kompanija Grimshaw Architecture je u fazi istraživanja tehnologije presvlačenja građevina materijalom koji skuplja vodu iz magle, po uzoru na numibijsku bubu Stenocara. Inače, istraživači sa MIT prvi su emulirali ovu sposobnost tako što su napravili površinu takve teksture koja kombinuje naizmenično raspoređene hidrofobične i hidrofilične materijale (Slika 3). Posle njih, komanija NBD Nano, sastavljena od dva biologa, organskog hemičara i mašinskog inženjera uspela je da napravi koncept 
samopunjujuće flaše. Spoljašnjost je superhidrofobična, a unutrašnjost superhidrofilična. Pretpostavka firme je da bi ovakva flaša moga da prikupi od pola litre do tri litre vode u zavisnosti od okruženja.

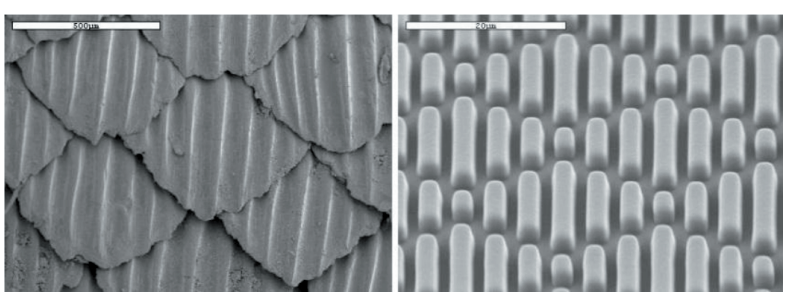

Slika 2. Obrazac i struktura kože ajkula (levo) i materijala Sharklet (desno).

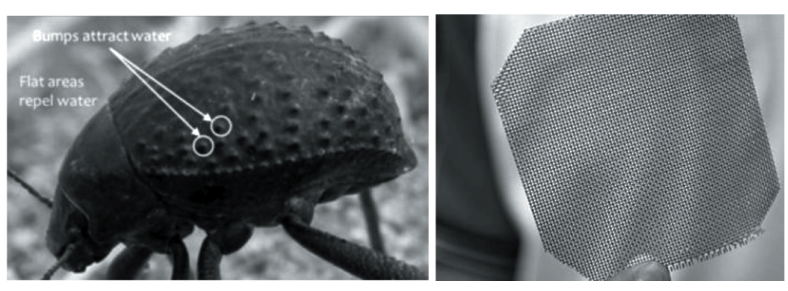

Slika 3. Prikupljanje vode iz atmosfere.

Priroda koristi ugljen-dioksid kao komponentu za gradnju. Uzor u prirodi su biljke, korali, školjke i slični organizmi. Firma Calera (USA) gradi cement i beton uz pomoć morske vode sa znatno manjom emisijom $\mathrm{CO} 2$ (Slika 4).

Sledeći primer je kreiranje solarnih ćelija po uzoru na način kojim lišće prikuplja energiju (Paul Hawken, firma OneSun). Firma OneSun radi na osvajanju tehnologija proizvodnje nove generaciju fotoosetljivih i veoma jeftinih solarnih ćelija. Ova fotonaponska tehnologija je novitet u dizajniranju ćelija sa potencijalom da se priozvede robustan, izdržljiv izvor energije. Ona je samomontažna i može da se postavi na bilo koji supstrat (Slika 5).

Akvaporini su integralni membranski proteini iz veće proteinske porodice glavnih unutrašnjih proteina, koji formiraju kanale pora u ćelijskim membranama. Njihova uloga je da regulišu protok vode kroz ćelijsku membranu, pri čemu se izdvajaju joni i drugi molekuli. Firma Aquaporins započela je istraživanja radi proizvodnje membrana za desalinaciju.

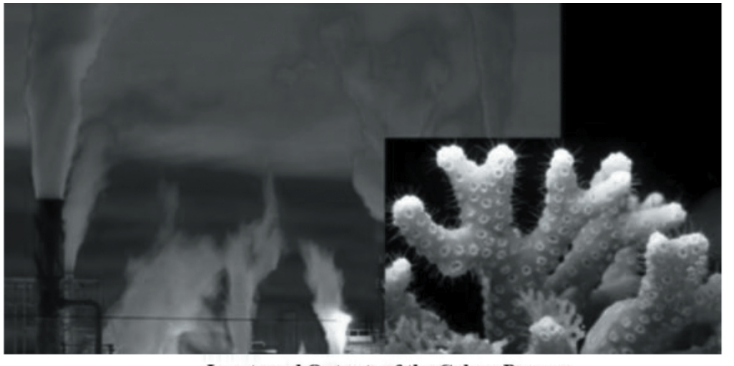

Inputs and Outputs of the Calera Process

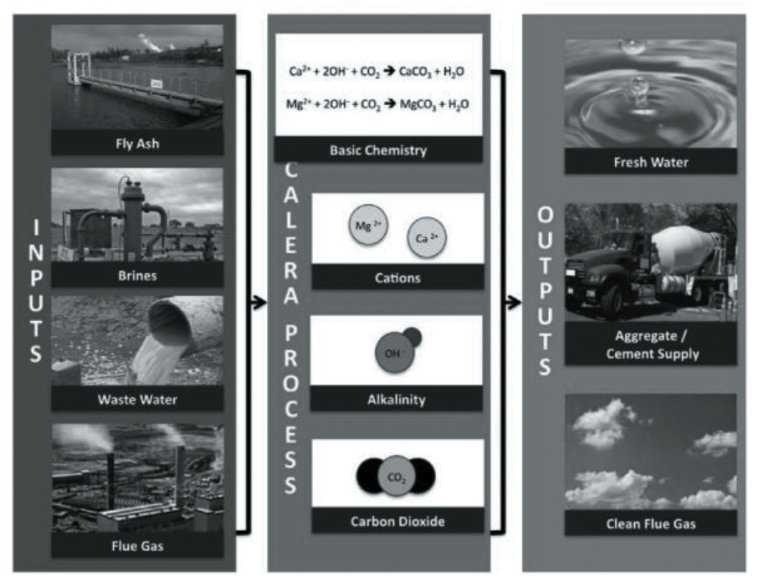

Slika 4. Calera proces proizvodnje cementa i betona.

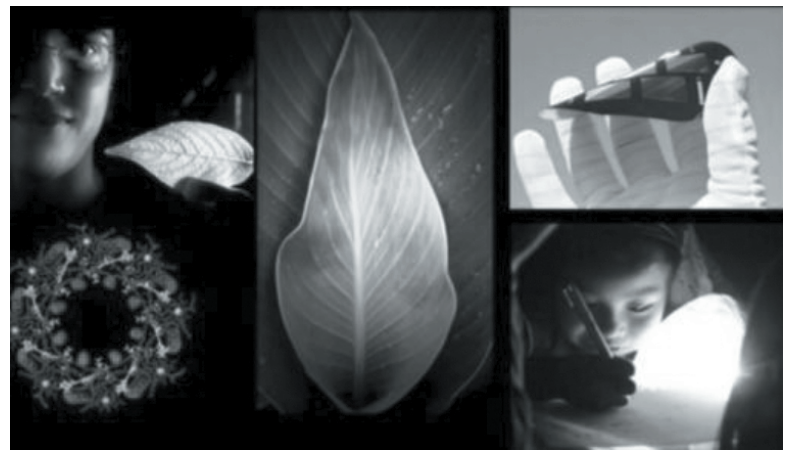

Slika 5. Nova generacija solarnih ćelija po uzoru na list.

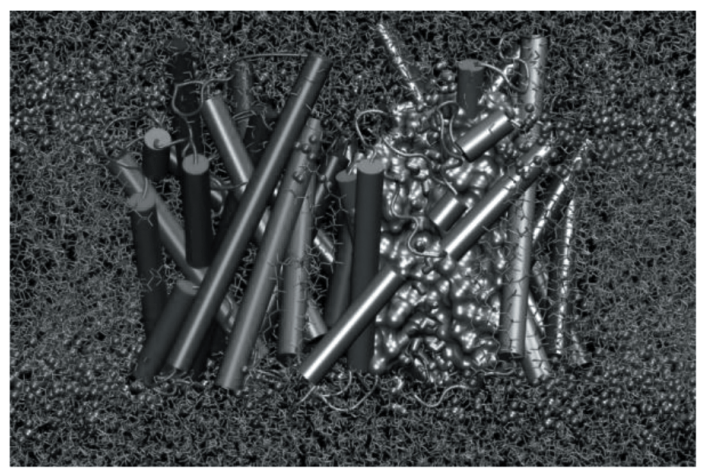

Slika 6. Akvapore u ćelijskoj membrani [http://www.ks.uiuc. edu/Research/aquaporins/Science-winning-image.jpg]. 
Stabla drveća i kosti konstantno se sami preoblikuju duž linija opterećenja. Ovaj algoritam unet je u softverski program koji se danas koristi za proračun lakih mostova, lakih građevinskih greda. Štaviše, Mercedes-Benz koristio je isti princip da izradu skeleta kod svojeg konceptualnog automobila - bioničkog auta. Algoritam je omogućio laku konstrukciju sa minimumom materijala, kao što to čini organizam, za maksimalnu nosivost.

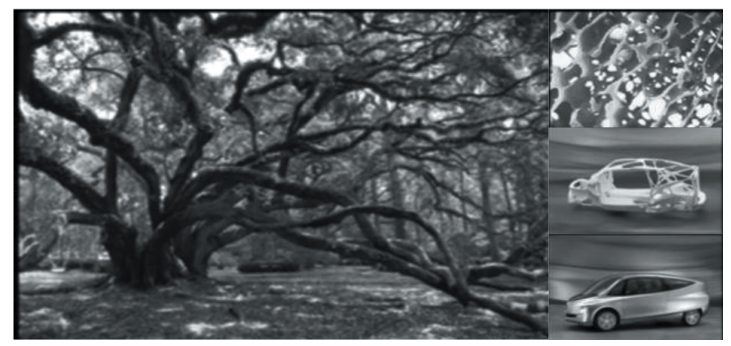

Slika 7. Kako priroda daje čvrstoću sa minimumom materijala.

Na Slici 8 prikazana je buba, krilo insekta i kesica čipsa. Buba koristi jedan materijal, hitin, i nalazi mnogo načina da u isti ugradi mnoštvo funkcija. Vodootporan je, snažan, otporan, propusan, stvara boju kroz svoju strukturu. Kesica čipsa, da bi ispunila ove funkcije, koristi sedam slojeva. Jedna od veoma važnih inovacija bila bi da se smanji količina materijala, vrsta materijala koja se koristi, i da se u takav materijal projektuje adekvatna funkcija. Priroda za sve svoje materijale koristi svega pet polimera, dok čovek koristi 350 da bi uradio iste stvari (Slika 9).

Priroda je u nanorazmeri. Međutim, nanotehnologija opasna je po pitanju slobodnih nanočestica. Priroda već dugo ima odgovor na ovo pitanje. Veoma dugo priroda ugrađuje nanočestice u materijal. Na primer, bakterija koja redukuje sumpor, kao deo svoje sinteze emituje (kao nusproizvod) nanočestice u vodi (Slika 10). Međutim, odmah posle toga emituje protein koji zapravo skuplja i spaja te iste nanočestice tako da ne budu deo rastvora.

Inženjeri koji se bave tretiranjem otpadnih voda naučili su mnogo iz prirode. Naime, do pre dvadesetak godina sistemi za prečišćavanje koristili su bakterije za pročišćavanje otpadnih voda. Ovo nije rešenje inspirisano prirodom, već bioasistirana tehnologija. Jedan od izazova jeste stvaranje i nagomilavanje minerala kroz cevovode. Zapravo, ova zagušenja nastaju od kalcijum-karbonata kamenca. Isti materijal od kojeg je napravljena školjka, na primer. Školjka, da bi zaustavila svoj rast, luči protein koji zaustavlja proces kristalizacije. Zahvaljujući ovom biomimikrijskom pristupu, danas postoji proizvod koji se zove TPA (termalni poliaspartat). Kompanija NanoChem Solutions Inc. (bivša Donlar Corp.) trenutno razvija i prodaje biorazgradivi polimer TPA kao deterdžent, dispersant, za tretiranje industrijskih otpadnih voda itd. (Slika 11).
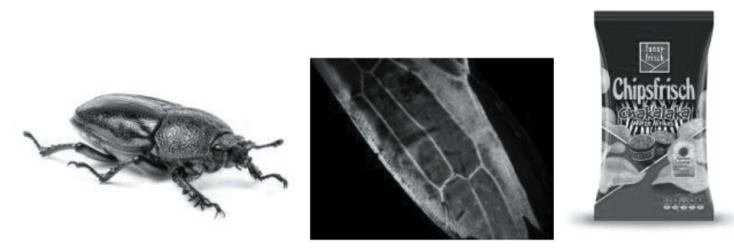

Slika 8. Višefunkcionalni materijal.

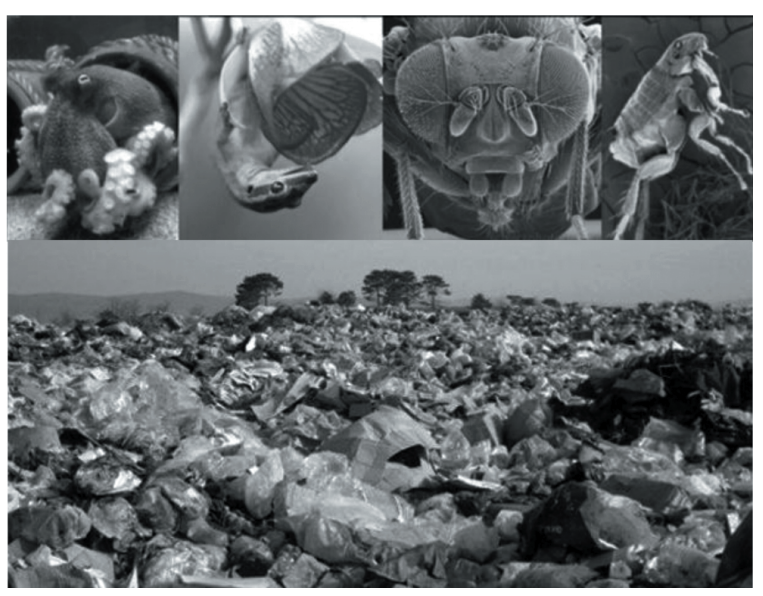

Slika 9. Priroda koristi pet polimera (gornji red), a čovek 350 (donji red).

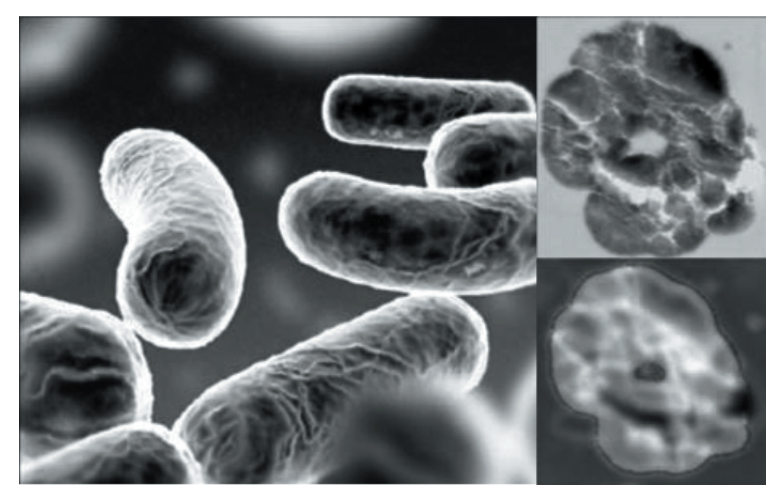

Slika 10. Prirodan način obezbeđenja nanočestica. 


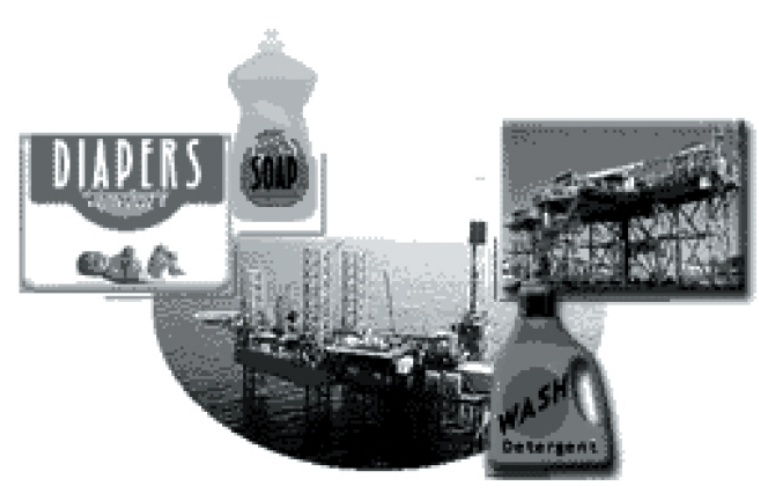

Slika 11. Proizvodi na bazi TPA.

\section{ZAKLJUČAK}

Savremeni i inovativni inženjerski i tehnološki studijski programi ključ su kvalitetnih budućih inženjera. Potrebno je da budući inženjeri budu pripremljeni da se suoče sa problemima sa različitim holističkim pristupom koji uključuje biomimikriju. Razumevanje prirode, njenih sistema i ciklusa, kako se nastaje fenomen u prirodi i kako ljudi vide okruženje, obezbediće analogije i modele za stvaranje inovativnih rešenja, bilo da su u pitanju složeni globalni problem, ili da se uspori napredovanje tih problema.

Biomimikrijski pristup obezbeđuje dodatni alat pomoću kojeg se tradicionalne disciplinarne granice inženjerskih i tehnoloških studijskih programa pomeraju. Na ovaj način, rešenja više ne leže unutar domena, nauke ili tehnologije. Umesto toga, pronalazak rešenja zahteva integrisani pristup preko više domena, nauka ili tehnologija. Primenjujući znanja o tome kako organski sistemi rade zajedno sa ljudskim sistemima, veze između deduktivnog razmišljanja (rešavanje problema) i reduktivnog razmišljanja (naučno istraživanje) omogući će da unapređeni studijski programi obezbede sposobnost da se prirodna, održiva rešenja, projektuju radi poboljšanja kvaliteta života svih zajednica.

Rezultat ovakve integracije trebalo bi da obezbedi problemski orijentisani pristup u kurikulumu studijskog programa tako da mogu da se razviju ključne inovativne sposobnosti i kompetencije neophodne za rešavanje globalnih problema. Posebno, trebalo bi da se omogući nov način da se traže odgovori na pitanja:

- Koja su potrebna znanja i uslovi za rešavanje složenih globalnih problema?

- Koji su izvori znanja o prirodi koji mogu da se primene?
- Kako se to znanje može raščlaniti i ograničiti?

Primena ovakvog kritičkog razmišljanja u velikoj meri doprinosi rešavanju i upravljanju složenim globalnim problemima sa kojim se čovečanstvo suočava. Nova, sveža i održiva rešenja, mogu da daju odgovore na snabdevanje energijom, klimatske promene, izumiranje vrsta, nedostatak hrane i vode, skladištenje i smanjenje otpada.

\section{LITERATURA}

[1] Janine M. Benyus, Biomimicry: Innovation Inspired by Nature, Harper Perennial, 2002.

[2] O. Schmitt, (1969). Some interesting and useful biomimetic transforms. Conference Proceeding of the Third International Biophysics Congress, Boston, Mass., p. 297.

[3] Biomimetika, Wikipedia.org, https://en.wikipedia. org/wiki/Biomimetics

[4] M. Gandhi, How science imitates nature, (septembar 2010), http://www. peopleforanimalsindia.org/articles-by-maneka-gandhi/212-how-science-imitatesnature.html

[5] H. Yahya, Biomimetics: Technology Imitates Nature, Global Publishing, mart 2006., http://www.muslimlibrary.com/dl/books/English_biomime tics_technologu_imitates_nature.pdf

[6] K. Passino, Biomimicry for optimization, control, and automation, Springer-Verlag London Limited, 2005.

[7] J. Reap, (2010). Holistic biomimicry: A biologically inspired approach to environmentally benign engineering, Georgia Tech Institute, Doctoral Thesis, 2009.

[8] Biomimicry 3.8 Institute, Biomimicry taxonomy, 2012., http://www.bio mimicryinstitute.org/images//biomimicry_taxonomy.pdf

[9] C. Smith, J. Vincent, Biomimetics: technology transfer from biology to engineering, Transactions of The Royal Society A Mathematical Physical and Engineering Sciences, 2002, https://www.researchgate. net/publication/278126964_Biomimetics_technology_transfer_from_biology_to_engineering_-_Introduction

[10] R. Sagarin, Learning from the octopus: How secrets from nature can help us fight terrorist attacks, natural disasters, and disease, Basic Books, 2012.

[11] J. Barnes, S. Barnes, D. Dyrenfurth, An epistemological problem-centric approach to solving complex global problems. Paper presented at the Forum on Philosophy, Engineering \& Technology (fPET-2012), The Graduate University of the Chinese Academy of Sciences (GUCAS), Beijing, People's Republic of China. Manuscript submitted for publication. 
[12] V. Blok, B. Gremmen, Ecological Innovation: Biomimicry as a New Way of Thinking and Acting Ecologically, Journal of Agricultural and Environmental Ethics, 2016.

[13] S. Achiche, F. P. Appio, A. Martini, C. Beaudry, On Designers' use of Biomimicry Tools during the New Product Development Process: An Empirical Investigation, Technology Analysis \& Strategic Management, 2016, forthcoming

[14] H. Bruk, A. Gershon, S. Gupta, Enhancement of Mechanical Engineering Curriculum to Introduce Manufacturing Techniques and Principles for Bioinspired Product Development, Proceedings of IMECE2004: 2004 ASME International Mechanical Engineering Congress and RD\&D Expo, November 13-19, 2004.

[15] M. Glier, D. McAdams, J. Linsey, Concepts in Biomimetic Design: Methods and Tools to Incorporate Into A Biomimetic Design Course, Proceedings of the ASME 2011 International Design Engineering Technical Conferences \& Computers and Information in Engineering Conference, IDETC/CIE 2011 August 28-31, 2011
[16] J. Nagel, R. Pidaparti, C. Rose, C. Beverly, Enhancing the Pedagogy o Bio-inspired Design in an Engineering Curriculum, ASEE $123^{\text {rd }}$ Annual Conference \& Exposition, New Orleans, USA, June 26-29, 2016.

[17] Julia E King, Educating Engineers for the 21st Century, The Royal Academy of Engineering, June 2007.

[18] Board on Testing and Assessment. (2011). Assessing 21st century skills: Summary of a workshop. Washington, DC: National Academies Press. http://www. nap.edu/catalog.php?record_id $=13215$

[19] J. Angeles, R. Britton, L. Chang, F. Charron, P. Gregson, P. Gu, P. Lawrence, W. Stiver, D. Strong, P. Stuart, P. Thompson, (2004). The Engineering Design Competency. [In Proceedings of the Inaugural CDEN Design Conference], July 29-30, Montreal, QC, Canada.

[20] Committee on the Engineer of 2020, Phase II, Committee on Engineering Education, National Academy of Engineering. (2005). Educating the Engineer of 2020: Adapting Engineering Education to the New Century. Washington, DC: National Academies Press. http://www.nap.edu/catalog/11338.html

\section{DEVELOPING NOVEL COMPETENCIES FOR ENGINEERING AND TECHNOLOGY STUDENTS}

\begin{abstract}
:
Due to the emerging advancements in science and technology, and with the enormous expansion of knowledge the problems of today must be addressed in a different way. Solution is not bound within a domain, science or technology. To solve global problem of today an integrated approach across many domains, sciences and technologies is needed. Human knowledge and understanding is limited by experience, education and research. Unfortunately, advancements in science and technology require more than this. Reviewing existing literature and innovations in the world, the authors of this paper wish express a study that will show a need for new capabilities and competencies for future engineers, thinking in a different way. It is the biomimicry approach that enables confronting the global problems in order to create a sustainable world. This is why engineering and technology study programs have to translate to a more global model; a model that would integrate the biomimicry approach as a means to prepare future engineers in different way, a more innovative way to tackle the global problems of today.
\end{abstract}

\section{Keywords:}

biomimicry, education, compentence. 